\title{
A gel-free approach in vascular smooth muscle cell proteome: perspectives for a better insight into activation
}

\author{
Silvia Rocchiccioli ${ }^{1}$, Lorenzo Citti ${ }^{1}$, Claudia Boccardi ${ }^{1}$, Nadia Ucciferri ${ }^{1,2}$, Lorena Tedeschi ${ }^{1}$, Caterina Lande ${ }^{1,2}$, \\ Maria Giovanna Trivella', Antonella Cecchettini ${ }^{2}$
}

\begin{abstract}
Background: The use of chromatography coupled with mass spectrometry (MS) analysis is a powerful approach to identify proteins, owing to its capacity to fractionate molecules according to different chemical features. The first protein expression map of vascular smooth muscle cells (VSMC) was published in 2001 and since then other papers have been produced. The most detailed two-dimensional polyacrylamide gel electrophoresis (2D-PAGE) map was presented by Mayr et al who identified 235 proteins, corresponding to the 154 most abundant unique proteins in mouse aortic VSMC. A chromatographic approach aimed at fractionating the VSMC proteome has never been used before.

Results: This paper describes a strategy for the study of the VSMC proteome. Our approach was based on prefractionation with ion exchange chromatography coupled with matrix assisted laser desorption-time of flight mass spectrometry analysis assisted by a liquid chromatography (LC-MALDI-TOF/TOF). Ion exchange chromatography resulted in a good strategy designed to simplify the complexity of the cellular extract and to identify a large number of proteins. Selectivity based on the ion-exchange chemical features was adequate if evaluated on the basis of protein pl. The LC-MALDI approach proved to be highly reproducible and sensitive since we were able to identify up to 815 proteins with a concentration dynamic range of 7 orders of magnitude.
\end{abstract}

Conclusions: In our opinion, the large number of identified proteins and the promising quantitative reproducibility made this approach a powerful method to analyze complex protein mixtures in a high throughput way and to obtain statistical data for the discovery of key factors involved in VSMC activation and to analyze a label-free differential protein expression.

\section{Background}

The use of chromatography coupled with MS analysis is a powerful approach for the identification of proteins, owing to its capacity to fractionate molecules with different chemical features [1-4]. Furthermore, LCMALDI-TOF/TOF analysis combined with preliminary fractionation of a total protein extract is a potential tool for biomarker discovery because of its high sensitivity and high throughput capacity [5].

However, the use of LC-MALDI analysis still needs to be optimized and evaluated [6,7]. To obtain useful

\footnotetext{
* Correspondence: acecch@biomed.unipi.it
${ }^{2}$ Department of Human Morphology and Applied Biology, University of Pisa,

* Correspondence: acecch@biomed.unipi.it
2Department of Human Morphology and Applied Biology, University of Pisa, Via Roma 55, 56126 Pisa, Italy
}

(c) 2010 Rocchiccioli et al; licensee BioMed Central Ltd. This is an Open Access article distributed under the terms of the Creative Commons Attribution License (http://creativecommons.org/licenses/by/2.0), which permits unrestricted use, distribution, and reproduction in any medium, provided the original work is properly cited.

information for comparative analysis of samples and differential protein expression using a label-free approach in LC-MALDI techniques, the reproducibility in measuring $\mathrm{m} / \mathrm{z}$ abundances (peak intensity) and a linear relation between intensity and marker concentration are essential [8-10]. Moreover, although LC-MALDI MS/ MS analysis is a high mass precision technique, it is time consuming, especially if applied to a large number of samples. For this reason a good compromise between sample pre-processing and high performance liquid chromatography (HPLC) separation would be necessary to avoid the masking effect of high abundant proteins and to evidence hypothetical biomarkers.

We set up and assessed a strategy for rapid data collection coupled with good reproducibility and precision. 
We checked this approach in the very interesting model system represented by vascular smooth muscle cells (VSMC). The cells are characterized by the capability of switching from a contractile and completely differentiated to a proliferating, migratory phenotype. This change is mainly due to the stimulation from growth factors and cytokines that are responsible for cell activation. Activated VSMCs play a pivotal role in the onset and progression of cardiovascular diseases, causing the development of atheromatous plaque and restenotic lesions [11]. Therefore, great attention has been focussed on the study of these cells, in order to find the factors involved in the activation process and/or the biomarkers of the activated, pathological phenotype, since these factors could be the putative targets of specific, innovative therapeutic strategies. In this respect, a proteomic approach is necessary but, up until now, only a few works have been realized and the great majority carried out with the use of 2D-PAGE. The first map of VSMC protein expression was published in 2001 [12] and since then other papers have been produced [13-17]. The most detailed 2D-PAGE map was presented by Mayr et al [18] who identified 235 proteins, corresponding to the 154 most abundant unique proteins, in mouse aortic VSMC. However, this technique is slow, hindered by the limited dynamic range and not sufficiently sensitive, especially for the study of hypothetical biomarkers, which are likely to be expressed in very low concentrations.

For all these reasons, we streamlined a non-conventional, sensitive and reproducible proteomic strategy that allowed us to identify 815 non-redundant VSMC proteins. This approach can be easily adapted for more detailed research and exploited for future analyses in biomarker discovery.

\section{Results and Discussion}

VSMCs cultured under standard conditions with $10 \%$ FBS display a characteristic synthetic, activated phenotype (ON-VSMC) endowed with the ability of migrating and proliferating. Otherwise, when left in serum-free medium for three days or more, they assume a differentiated quiescent phenotype (OFF-VSMC) able to contract [19]. Serum growth factors and cytokines are known to be in charge of this phenotypic switch; moreover, this process is responsible for the onset and progression of the principal cardiovascular diseases. In order to optimize methods for the analysis of the activation mechanism which can eventually be exploited for biomarker discovery, we analyzed ON- and OFF-VSMC and also cells maintained for three days in absence of serum and then activated for 10 minutes with fetal bovine serum (FBS) (10'-VSMC). The effective change in cellular phenotype was checked as reported in the literature [20]. For all three protein extracts the workflow we adopted to analyze the VSMC proteome is reported in figure 1.

Aim of ion-exchange chromatography is to simplify the total proteome of the cell extract and to avoid the masking effect due to the excessive complexity and presence of highly abundant proteins [21].

After sample pre-processing (anion- and cationexchange resins), a relatively short HPLC run of a 30 min gradient was chosen in order to obtain a suitable separation of the peptides and to avoid peptide redundancy in contiguous spots due to an inefficient gradient rate. The fractions between 10 and 50 minutes were spotted resulting in approximately 200 spots per sample, but a preliminary analysis evidenced that only the first 150 fractions were informative. This approach allowed the spotting of up to 6 samples (all samples of $\mathrm{ON}$, OFF, 10' for anion- and cation-exchange chromatography) on a single MALDI plate minimizing plate to plate signal variability, cost and time. The spots were analyzed using a 4800 MALDI-TOF/TOF mass spectrometer and the MS/MS data were pre-processed by the manufacturer computer program GPS Explorer and identified using the MASCOT search engine. To evaluate the possibility of comparing "control" and "activated" samples through the peptide area and to estimate the "quantitative" reproducibility of the MALDI signal intensity, we applied four replicated runs and we used an internal standard of known concentration (ACTH 18-39 fragment) diluted in the matrix (Figure 2). A significant correlation was found between spiked peptide concentration and intensity in the range of 5 to $20 \mathrm{fmol} / \mu \mathrm{l}$. The precision of the measure evaluated as mean CV\% between the four replicates was $9.95 \pm$ $1.35 \%$. As a matter of fact, even though MALDI ionization is known to yield poor reproducibility of peak intensity due to the heterogeneous co-crystallization of the matrix and the peptides [7], a high shot count (we used 5000 shots/spectra) could lead to greater reproducibility, as reported in the literature by Hattan et al [9].

To evaluate the efficiency of the ion-exchange resins we checked pI distribution of the identified proteins. We divided the identified proteins into three different $\mathrm{pI}$ ranges (3.69-8.99; 9.06-9.99 and 10-12.02) according to the acidic fraction, while for the cation-exchange the three pI fractions were 3.76-4.98; 5-5.98 and 6.01-12.02. Resin performance in terms of selectivity based on ionic properties proved to be very good, since $80 \%$ of the proteins bound to the anionic resin displayed an acid pI ( $\mathrm{pI}<8$ ) and $60 \%$ of the proteins isolated by the cationexchange showed basic $\mathrm{pI}(\mathrm{pI}>6)$. Furthermore, $73 \%$ of these basic proteins had $\mathrm{pI}>8$, indicating that this approach could be used to complement 2D-gel analysis where high pI proteins are under-represented [22]. 


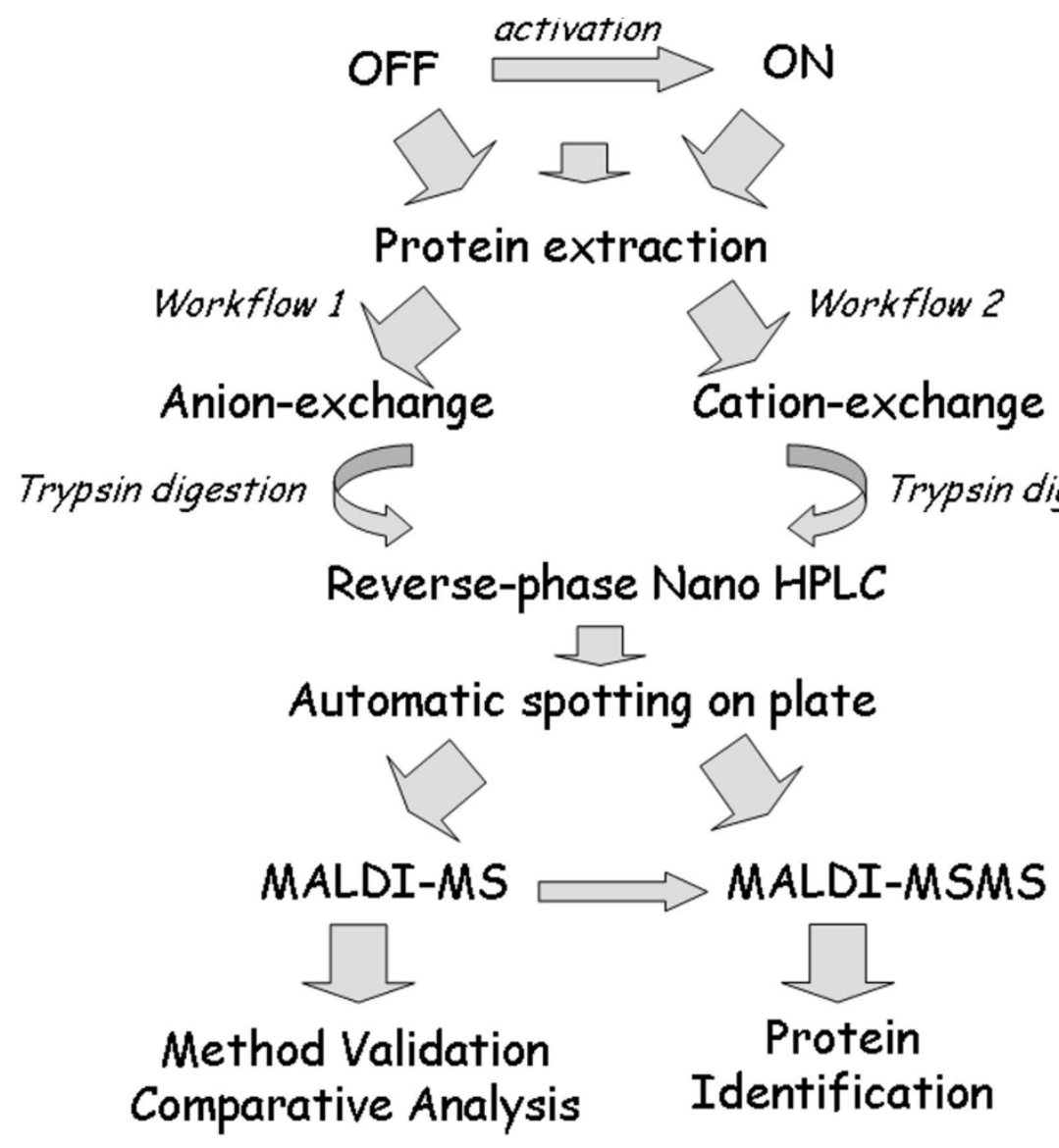

Figure 1 Experimental procedure. It summarizes the experimental procedure we adopted for our study. Proteins from ON- OFF- and 10'-VSMC were fractionated by ion-exchange chromatography (cation and anion), the 'specific sample solution' was tryptic digested and the peptides were separated by reverse-phase nano-HPLC before MALDI analysis.

A total of 815 unique proteins, each of them present in all technical replicates, has been obtained and the complete list is reported in "Table-TotalUniqueProteins" [see Additional file 1]. The samples (ON, OFF, 10') in which each protein has been identified are specified together with the chromatographic method (anion-, cation-exchange). 131 proteins are found only in the sample ON, 104 in the sample OFF and 133 in the sample 10', indicating that every fraction contributes to the total identified proteins. The number of matched peptides per protein is shown. Single hit proteins resulted to be 193 ; corresponding to $24 \%$ of the total protein content.

To estimate the sensitivity of the chromatographic method coupled to nano-LC-MALDI analysis, we evaluated the number of proteins isolated by both resins (anion- and cation-exchange). The dynamic range of concentration covered by this approach was more than 7 orders of magnitude: the most concentrated was actin, while we identified the heat shock protein beta 1 , a low concentrated marker [23]. After protein identification, we estimated the overlap percentage between anionexchange and cation-exchange, which turned out to be $21.8 \%$, suggesting that each resin tends to isolate different set of proteins. In particular, in the anion-exchange we isolated 480 unique proteins, while in the basic fraction we obtained 157 unique proteins. A total of 178 proteins resulted common to the two fractions. The proteins exclusively identified by the anion-exchanger represented almost $73 \%$ of all proteins, while those exclusively identified by the cation-exchanger were almost $47 \%$ of the total number of proteins identified. Even if the two pre-fractionation methods did not work identically, similar selection efficacies were demonstrated in the case of SCX and SAX columns for HPLC applications [24].

The identification of VSMC proteins from their peptide sequences was established with the Swiss-Prot database restricted to mammalian entries and the NCBI database restricted to Sus scrofa entries. A comparison was carried out between the two workflows on the basis of the number of proteins identified by using both 


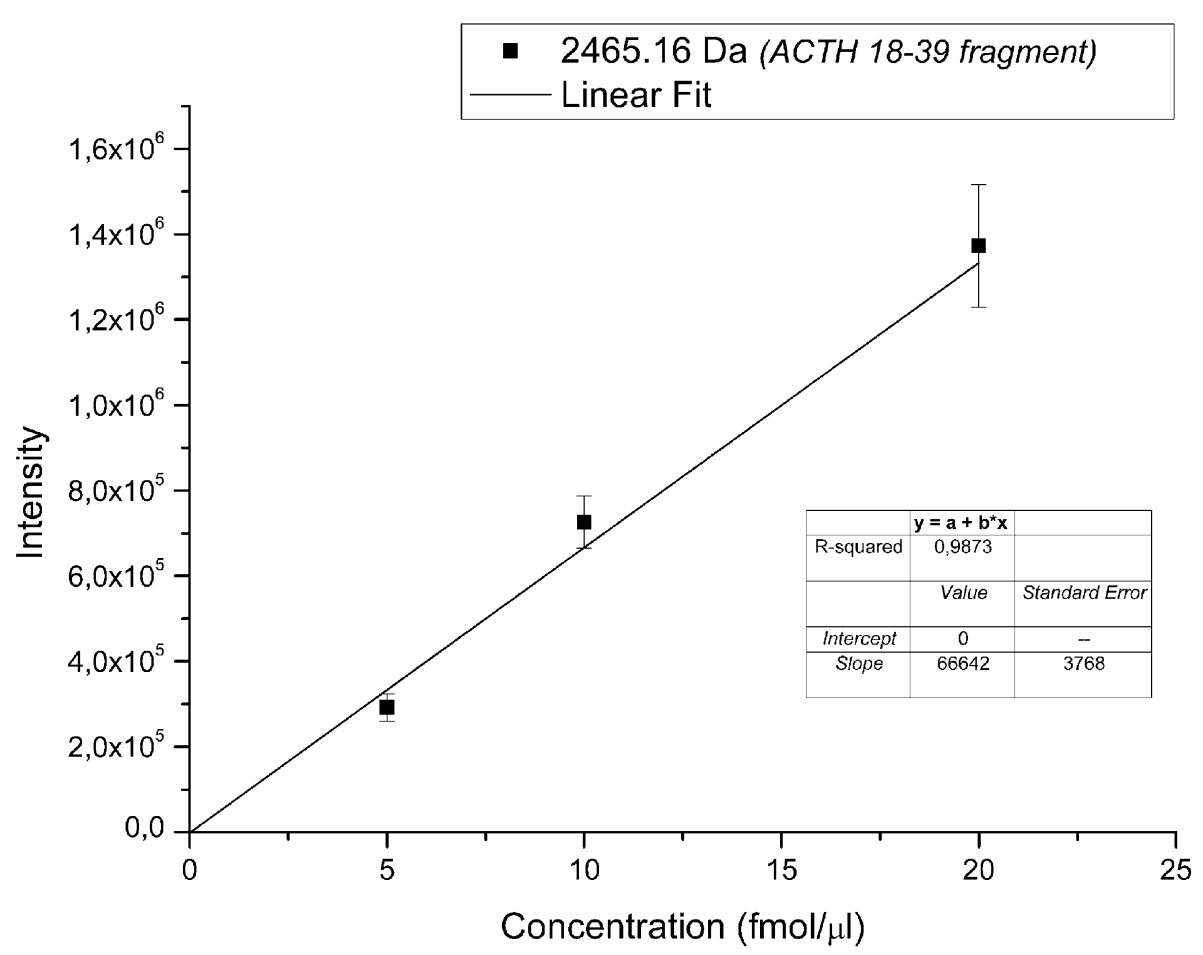

Figure 2 Plot Concentration/Area signal of ACTH standard peptide. It shows the plot of the area/concentration of a standard peptide (ACTH 18-39 clip, 2465.16 Da) after MALDI-MS analysis by 5000 shots/spot. We performed four replicated runs for each known concentration (5, 10 and $20 \mathrm{fmol} / \mu \mathrm{l}$ ) of the standard peptide.

databanks. Table 1 evidences the efficiency of MALDI analysis in mapping the VSMC proteome.

Sensitivity is enhanced with respect to the classical 2D-PAGE without pre-fractionation steps [17] using pre-treatment with ion-exchange chromatography that avoids the mask effect due to the complexity of the whole cell protein extract.

The metric for the success of this study was to maximize sample information concerning identified peptides, number of proteins and minimum overlap between cation and anion exchange. The efficiency of the MALDI analysis strongly influences peptide identification and can be assessed by MSMS efficiency which compares the number of MSMS spectra with the number of identified peptides. We obtained a good performance in both cases and the comparison of MSMS efficacy in the two databanks reflects the strong dependence of sequence identification on the analysis settings used. While peptides identified by the SwissProt database all match for annotated protein sequences, peptides recognized by the NCBI databank only partially match for annotated proteins, more than half being predicted by genome annotations. The number of peptides for each protein (calculated as an average between the number of peptides

Table 1 Comparison of MALDI efficiency for the workflows with two databanks

\begin{tabular}{|c|c|c|c|c|c|c|c|c|}
\hline workflow & $\begin{array}{c}\text { MS } \\
\text { Spectra }^{a}\end{array}$ & $\begin{array}{c}\text { MSMS } \\
\text { Spectrab) }^{\text {Mpection }}\end{array}$ & $\begin{array}{c}\text { Identified } \\
\text { peptides }\end{array}$ & $\begin{array}{c}\text { MSMS } \\
\text { efficiency } \\
(\%)^{c)}\end{array}$ & Proteins $^{d)}$ & $\begin{array}{l}\text { peptides/ } \\
\text { proteins }\end{array}$ & $\begin{array}{l}\text { Proteins by single } \\
\text { peptide }^{\text {e) }}\end{array}$ & DataBank $^{\text {f) }}$ \\
\hline 1 (Anion) & 597 & 6868 & 3530 & $51 \%$ & 658 & 5.4 & 141 & $\begin{array}{l}\text { SwissProt } \\
\text { (Mammalia) }\end{array}$ \\
\hline 2 (Cation) & 597 & 6212 & 2705 & $43 \%$ & 335 & 8.1 & 139 & $\begin{array}{l}\text { SwissProt } \\
\text { (Mammalia) }\end{array}$ \\
\hline 1 (Anion) & 597 & 6868 & 4232 & $62 \%$ & $\begin{array}{c}900 \\
\text { (555Pred) }\end{array}$ & 4.07 & 53 & $\begin{array}{c}\text { NCBI } \\
\text { (Sus Scrofa) }\end{array}$ \\
\hline 2 (Cation) & 597 & 6212 & 3317 & $54 \%$ & $\begin{array}{c}720 \\
\text { (467Pred) }\end{array}$ & 4.07 & 34 & $\begin{array}{c}\mathrm{NCBI} \\
\text { (Sus Scrofa) }\end{array}$ \\
\hline
\end{tabular}

a) number of total MS spectra/workflow; b) number of total MSMS spectra/workflow; c) efficiency is determined dividing the number of identified peptides per MSMS spectra; d) number of unique identified proteins. "Pred" is an abbreviation for "Predicted" e) number of proteins identified by a single peptide as reported by GPS Explorer software; f) database chosen in protein identifications in GPS Explorer software. 
and number of proteins) is lower in NCBI analysis than in SwissProt setting, but in NCBI analysis the number of proteins identified by a single peptide evidences a better distribution of the peptides within the proteins.

After optimization of pre-fractionation and nanoLC-MALDI performance, we made a first attempt to compare the protein contents of activated ON-VSMC and quiescent OFF-VSMC obtained by anion-exchange. Significant differences between ON and OFF cells are made evident by simply comparing their UV profiles after HPLC separation of the peptide mixtures. Instead, the 10'-VSMC and OFF-VSMC UV profiles are strictly superimposed (Figure 3) as we expected, since in the early phase of activation post-translational modifications such as phosphorylation generally occur, while a differential protein expression is untimely [25]. For these reasons, to analyze the differences between activated and quiescent cells we concentrated our attention on $\mathrm{ON}$ and OFF samples.

The identified proteins in anion-exchange were grouped in functional classes and the differences between ON and OFF cells reported in figure 4. As a preliminary result, we can observe that major variations are related to cytoskeleton, chaperones, cell cycle, factors associated with protein synthesis and enzyme responsible of the energetic metabolism.

It is first interesting to observe how chaperones and enzymes involved in protein synthesis and energy metabolism are outnumbered in the activated cells. This phenotype is in fact characterized by the incentive of proliferation and migration and also by an impressive increase in protein synthesis $[11,26]$. It is encouraging to observe that proteins related to migration are more represented in activated cells (4\% vs $2 \%$ ), while the opposite is true for cytoskeleton elements implied with contraction (13\% vs $24 \%$ ). Moreover, proteins involved in the inhibition of cell proliferation or apoptosis are more numerous in quiescent VSMC, but proteins activating cell cycle progression are more represented in activated VSMC ( $5 \%$ vs $1 \%$ ).

A preliminary comparative investigation was carried out to analyze the differential peptide and protein expression in the two different phenotypes. We used the aligned peak lists obtained by MarkerView [27] and two technical replicates for every sample (quiescent-OFF and activated-ON VSMC), with particular attention to some proteins clearly involved in functions undoubtedly stimulated by the growth factor. Identified peptides corresponding to a given protein were analyzed in order to follow the general trend. The result was encouraging since for the majority of the factors related to cytoskeleton remodelling responsible for cell motility an overexpression in activated VSMC was evidenced. We report the results obtained for two proteins, as examples (Figure 5).

VSMCs grown with 10\% FBS for up to three days (ON) display completely different features and functions compared to the contractile-quiescent cells cultured in absence of serum (OFF); as a matter of fact, the existence of two distinctive phenotypes, one contractile and healthy, the other activated and pathological, has long been recognized.

\section{Conclusions}

Ion-exchange chromatography is a suitable strategy aimed at simplifying the complexity of the cellular extract and at identifying a large number of proteins. The efficiency based on the ion-exchange chemical
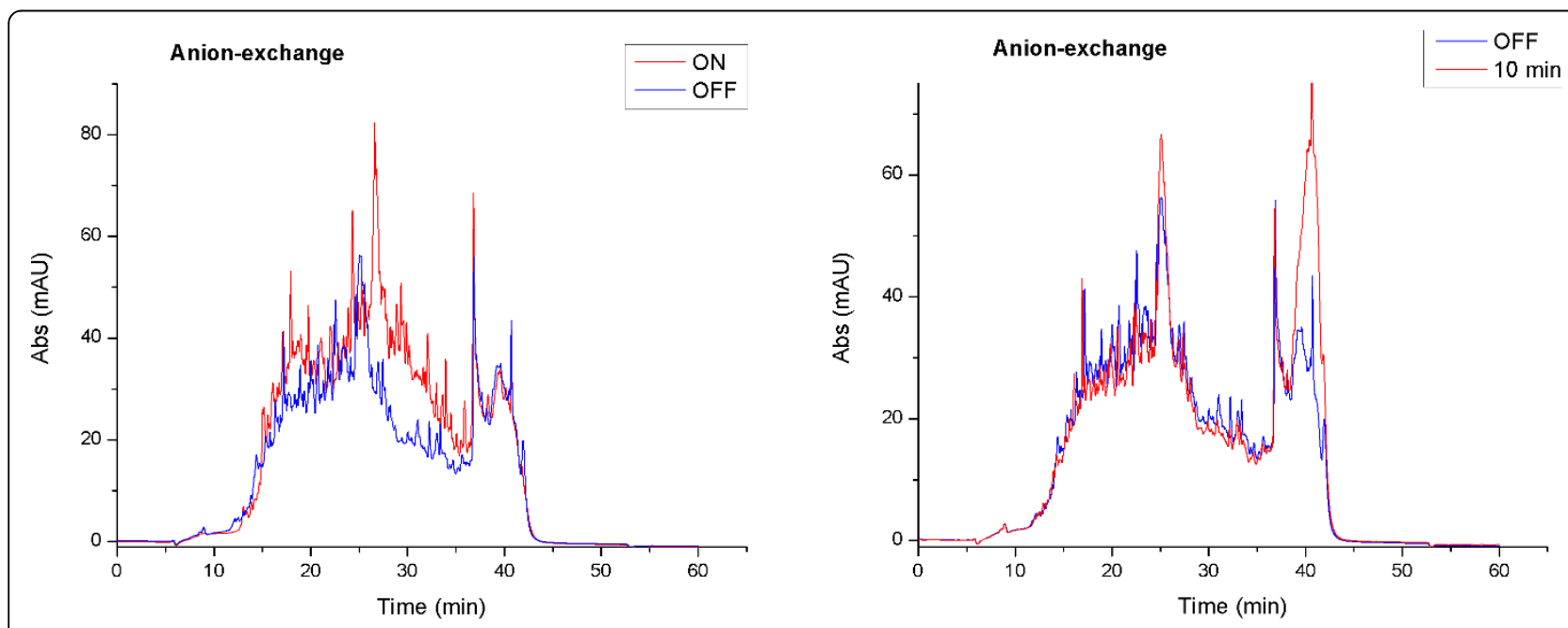

Figure 3 HPLC UV Profile Overlap. It shows the overlap of the UV profiles, measured by nano-HPLC at 214 nm wavelength of anion-exchange LC-runs in ON, OFF and 10 min "specific sample solutions" 


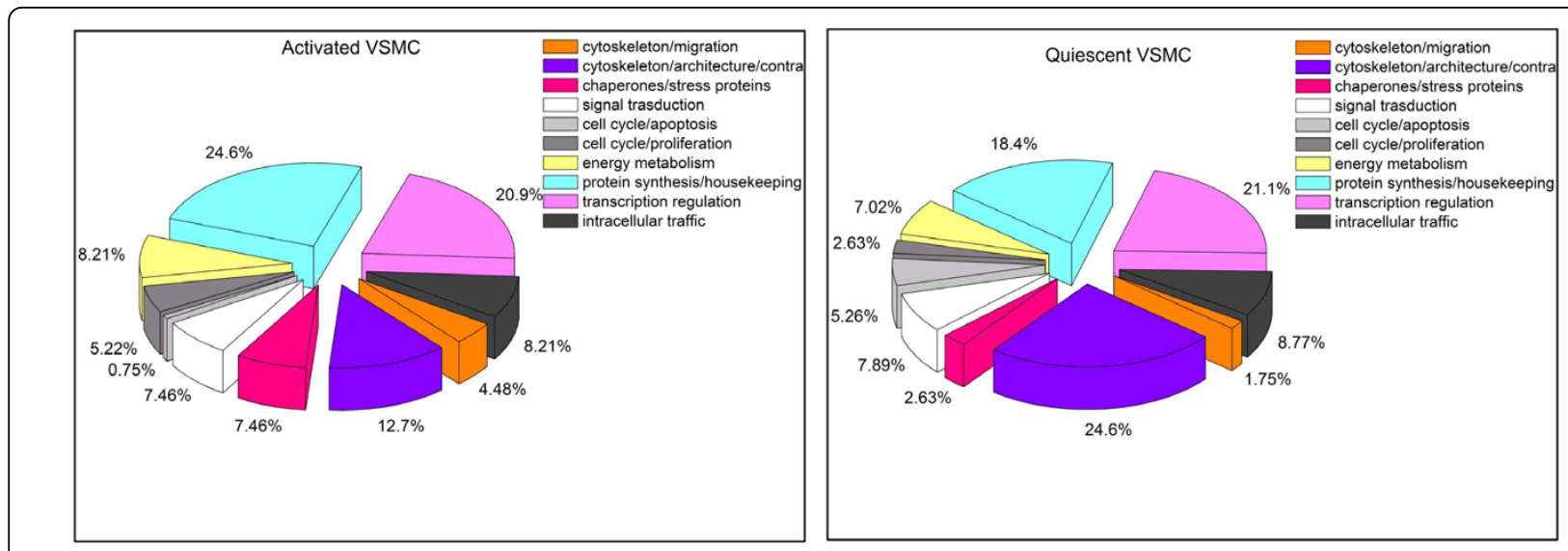

Figure 4 Classification of identified proteins. It shows identified protein distribution by selected functions respectively for ON and OFF cells.

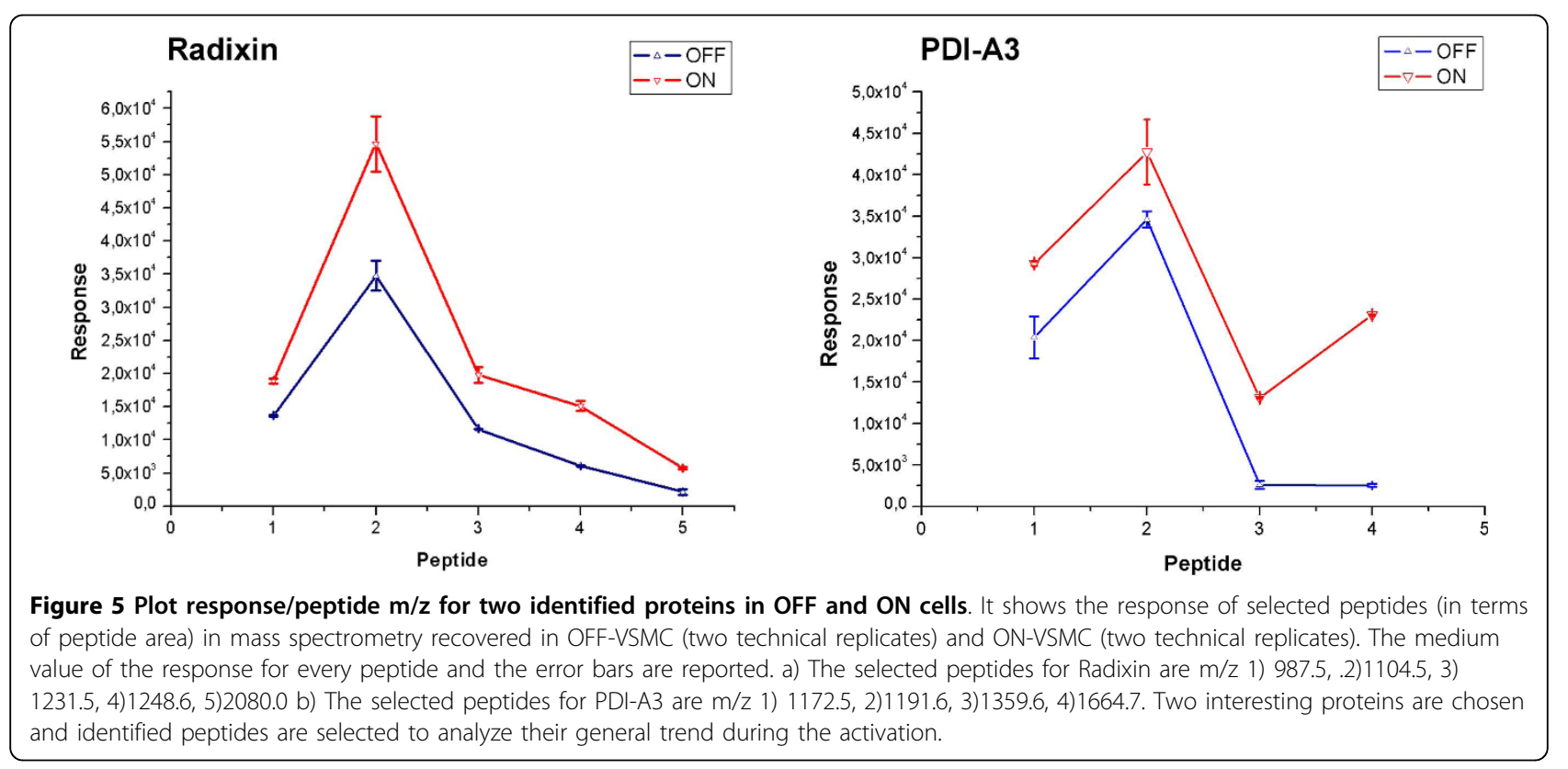

features was good if evaluated on the basis of the protein pI. The LC-MALDI approach was reproducible and sensitive since we were able to identify up to 815 proteins with a dynamic range of 7 orders of magnitude. Moreover, this approach could be easily integrated with other chromatographic media, more useful and selective for post-translational modifications and phospho-specific chromatographic methods such as IMAC, SIMAC or $\mathrm{TiO}_{2}$ useful to analyze the early events of VSMC activation. In our opinion, the large number of identified proteins and the promising quantitative reproducibility have made this approach a powerful method to analyze complex protein mixtures in a high throughput way and to obtain statistical data for the discovery of key factors involved in VSMC activation and to analyze a label-free differential protein expression.

\section{Methods}

\section{Chemicals, standards and consumables}

ACN and TFA used for LC-MS analysis or sample preparation were of HPLC quality (Sigma Aldrich, St Louis, USA); HPLC-grade water was prepared by a Milli-Q purification system (Millipore, Billerica, MA, USA); sequencing-grade trypsin for protein digestion was from Roche (Mannheim, Germany). BCA-Protein Assay for the determination of protein concentration was from Pierce (Rockford, IL, USA). All other chemicals used for sample preparation were reagent-grade from Sigma (St Louis, MO, USA).

\section{Isolation of VSMC and culture conditions}

Coronaries were dissected from the myocardium of 8-month-old domestic crossbred pigs (Sus scrofa 
domestica). Medial VSMCs were isolated by enzymatic digestion and cultured according to the method described by Christen et al [19]. All experiments reported in this study were performed with VSMC at the sixth passage and, unless otherwise specified, from at least three different explants. The investigation was conformed to the Ministerial Decree to authorize testing n.06/2009-B of 26/01/2009.

\section{Protein extraction}

VSMC pellets from about $10^{7}$ VSMCs were suspended in $500 \mu \mathrm{l}$ of ice-cold lysis medium containing $50 \mathrm{mM}$ Tris- $\mathrm{HCl} \mathrm{pH} 8 ; 0.5 \%$ Triton X-100; 0.25\% deoxycholic acid. Cells were sonicated (SoniPrep 150 MSE) 5 times (10 seconds sonication and 20 seconds rest in ice) and centrifuged (Centrifuge Eppendorf 5415R and a standard rotor F45-24-11, $11 \mathrm{~mm}$ diameter) at $10500 \times \mathrm{g}$ at $4^{\circ} \mathrm{C}$ for $30 \mathrm{~min}$, gently vortexed and re-centrifuged for 15 min under the same conditions. The protein concentration was determined by BCA (bi-cinchoninic acid) and the protein samples were lyophilized.

\section{Protein fractionation}

$1.2 \mathrm{mg}$ of each protein sample (OFF-quiescent cells, ON-activated cells, 10'-cells activated for 10 minutes with FBS) was re-suspended in $100 \mu \mathrm{l}$ of water and split in two parts, one for anion-exchange chromatographic fractionation and the other for cation-exchange.

\section{Cation-exchange chromatographic fractionation}

Cation-exchange columns were prepared using Mobicol column (Mo Bi Tec, Göttingen, Germany) filled with $250 \mu \mathrm{l}$ of strong cation-exchanger resin $(500 \mu \mathrm{l}$ of slurry Unosphere S, Biorad). Each resin was centrifuged to remove the storage solution. They were washed with formic acid/ $\mathrm{NH}_{3}$ pH 5.7 (binding buffer I) and centrifuged at $9300 \times \mathrm{g}$ for $30 \mathrm{sec}$; the wash was repeated twice. $450 \mu \mathrm{l}$ of binding buffer I were added to the samples. The obtained solutions were loaded and fluttered up-down on the column for $15 \mathrm{~min}$ at $4^{\circ} \mathrm{C}$. The columns were centrifuged at $9300 \times \mathrm{g}$ for $30 \mathrm{sec}$ and washed with $150 \mu \mathrm{l}$ of binding buffer I. The aspecific sample was discarded. Columns were washed with 0.5 $\mathrm{ml}$ of binding buffer I, vortexed and centrifuged twice at $9300 \times \mathrm{g}$ for $30 \mathrm{sec}$ and the operation was repeated with $0.5 \mathrm{ml}$ of water to favour $\mathrm{pH}$ change.

Elution of the specific fractions was carried out with $0.5 \mathrm{ml}$ of elution buffer containing $5 \% \mathrm{NH}_{4} \mathrm{OH}, 1 \mathrm{M}$ $\mathrm{NaCl}, \mathrm{pH}$ 11.8. The columns were fluttered up-down for $15 \mathrm{~min}$ at $4^{\circ} \mathrm{C}$, centrifuged at $9300 \times \mathrm{g}$ for $30 \mathrm{sec}$ and washed twice with $150 \mu$ l of elution buffer; the eluted was stored (named "specific" cationic sample solution). All samples were lyophilized.

\section{Anion-exchange chromatographic fractionation}

Anion-exchange columns were prepared using Mobicol column (Mo Bi Tec, Göttingen, Germany) filled with $250 \mu \mathrm{l}$ of strong anion-exchanger resin $(500 \mu \mathrm{l}$ of slurry Unosphere Q, Biorad). Each resin was centrifuged to remove the storage solution. They were washed with $200 \mathrm{mM}$ Tris/ $\mathrm{HCl}, \mathrm{pH} 8.5$ (binding buffer II) and centrifuged at $9300 \times \mathrm{g}$ for $30 \mathrm{sec}$; the wash was repeated twice. $450 \mu \mathrm{l}$ of binding buffer II were added to the samples. The obtained solutions were loaded and fluttered up-down on the column for $15 \mathrm{~min}$ at $4^{\circ} \mathrm{C}$. The columns were centrifuged at $9300 \times \mathrm{g}$ for $30 \mathrm{sec}$ and washed with $150 \mu \mathrm{l}$ of binding buffer II. The aspecific sample was discarded. Columns were washed with $0.5 \mathrm{ml}$ of binding buffer II, vortexed and centrifuged twice at $9300 \times \mathrm{g}$ for $30 \mathrm{sec}$ and the operation was repeated with $0.5 \mathrm{ml}$ of water to favour $\mathrm{pH}$ change.

The columns were fluttered up-down for $15 \mathrm{~min}$ at $4^{\circ}$ $\mathrm{C}$, centrifuged at $9300 \times \mathrm{g}$ for $30 \mathrm{sec}$ and washed twice with $150 \mu \mathrm{l}$ of elution buffer ( $200 \mathrm{mM}$ formic acid/ $\mathrm{NH}_{3}$ $\mathrm{pH}=2.5$ ); the eluted was stored and named "specific" anionic sample solution. All samples were lyophilized.

\section{Reduction, alkylation and digestion}

Lyophilized protein mixtures of samples were suspended in $250 \mu \mathrm{l}$ of $20 \mathrm{mM}$ ammonium hydrogen carbonate $\mathrm{pH}$ 8. Reduction was performed adding $25 \mu \mathrm{l}$ of $50 \mathrm{mM}$ DTT to each sample which was made to react at $80^{\circ} \mathrm{C}$ for $20 \mathrm{~min}$. Samples were allowed to cool at room temperature and $12.5 \mu \mathrm{l} 200 \mathrm{mM}$ iodoacetamide were added for $30 \mathrm{~min}$ at $37^{\circ} \mathrm{C}$. Digestion was performed adding $7.5 \mu \mathrm{l}$ of trypsin solution (solution $0.25 \mathrm{mg} / \mathrm{ml}$ ) at $37^{\circ} \mathrm{C}$ overnight.

\section{Peptide separation using Nano-HPLC}

Chromatographic separation of peptides was performed using an Ultimate 3000 nano-HPLC system (LC Packings, DIONEX, Sunnyvale, USA). $37.5 \mu \mathrm{l}$ of $0.2 \%$ TFA up to 150 $\mu \mathrm{l}$ with water was added to $50 \mu \mathrm{l}$ of each sample and filtrated with $0.45 \mu \mathrm{m}$ filter. The loading pump ensured preconcentration of the sample in a $\mu$-precolumn cartridge (PepMap-100 C18 $5 \mu \mathrm{m}$ 100A, $30 \mu \mathrm{m}$ idx 5 mm). Chromatographic separation of peptides was performed using a C18 PepMap-100 column ( $15 \mathrm{~cm} \times 75 \mu \mathrm{m}$ i.d., LC Packings DIONEX) and using a linear gradient of $\mathrm{B}$, a mixture of acetonitrile/water (80:20) with $0.05 \% \mathrm{TFA}$, in solvent $\mathrm{A}$, a mixture of water/acetonitrile (98:2) with $0.04 \%$ TFA as follows: from $10 \%$ to $45 \%$ of $\mathrm{B}$ in $30 \mathrm{~min}$, switched to $100 \%$ buffer B for $10 \mathrm{~min}$, followed by $20 \mathrm{~min}$ re-equilibration with buffer $\mathrm{A}$ at a constant flow rate of $0.3 \mu \mathrm{l} / \mathrm{min}$. The column was directly coupled to a UV flow cell detector (214 nm-Ultimate DIONEX) at the exit of which the effluent was coaxially mixed with a solution of $2 \mathrm{mg} / \mathrm{ml} \alpha$ cyano-4-hydroxycinnamic acid MALDI matrix ( $\alpha$-CHCA) 
(Sigma-Aldrich, St Louis, MO, USA) prepared daily and delivered at a flow rate of $1.9 \mu \mathrm{l} / \mathrm{min}$, then directed towards an on-line Probot (LC Packings DIONEX) platespotting system (MALDI plate containing 1664 total wellsABSCIEX). The injection of each sample was replicated twice. Before and after sample analysis, two blank injections were performed to minimize carry-over. Each spot represented a 12-second "fraction" of the reverse phase gradient. The runs of each sample, each containing 200 spots, were distributed on the same MALDI plate.

\section{MALDI MS data acquisition}

Spots representing the different chromatographic fractions were analyzed using a 4800 MALDI-TOF/TOF mass spectrometer (Applied Biosystems/MDS Sciex, Toronto, Canada), equipped with a laser emitting at $\lambda=$ $355 \mathrm{~nm}$ with a repetition rate of $200 \mathrm{~Hz}$. The mass spectrometer was controlled by the 4000 Series Explorer, version 3.5.2 program. For MS analyses, typically 2000 spectra were acquired for each spot in the reflector positive mode in the mass range of 650 to $4000 \mathrm{~m} / \mathrm{z}$, with $50 \mathrm{ppm}$ mass tolerance (external and internal calibration). The spots of fractions eluted before $10 \mathrm{~min}$ and after $50 \mathrm{~min}$ were not analyzed for the sake of time, as preliminary investigations showed that they apparently contained very little peptide information.

\section{MS data processing and analysis}

Peak lists obtained from Nano-LC-MALDI-TOF chromatograms were processed using MarkerView version 1.2 (Applied Biosystems/MDS Sciex, Toronto, Canada). Alignment was first performed with 2 min retention time and $0.2 \mathrm{amu}$ mass tolerance for all technical replicates of OFF- and ON-VSMC. These settings were optimized values found to give a maximum number of common peaks between samples. Then, the data were scaled in intensity by normalization by total area sum using MarkerView. After alignment and normalization, the data were filtered out from MALDI residual $\alpha$ CHCA matrix clusters. As most matrix clusters had masses below $700 \mathrm{~m} / \mathrm{z}$, filtration consisted in excluding all ions with $\mathrm{m} / \mathrm{z}<700$. The aligned peak lists were used to plot profiles of interest peptides in the activated vs non-activated samples and to extract preliminary information on differential peptide/protein expression.

\section{MALDI MSMS data acquisition and protein identification} MS/MS data acquisition was performed on all runs in the MALDI for the best 15 precursor ions. MS/MS acquisitions were then carried out using air as collision gas at a pressure of $\sim 3.0 \times 10^{6}$ torr and collision energy of $1 \mathrm{kV}$. Approximately 2000 spectra were added up for each spot. The peaks were de-isotoped and only those with $\mathrm{s} / \mathrm{n}>5$ were retained for interpretation.
MSMS data were pre-processed by the manufacturer computer program GPS Explorer version 3.6 (Applied Biosystems). Identification of pig proteins from their peptide sequences was established using MASCOT search engine version 2.1 (Matrix Science, Boston, MA) with the last updated version of Swiss-Prot protein database for Mammalia and UniGene database (NCBI) for Sus Scrofa (UniGene Built \#37 Entries: 51,692). Methionine oxidation, Asn and Gln deamidation, Thr, Ser and Tyr phosphorylation and acetylation were selected as variable modifications. The tolerance for precursor ion and MS/MS fragment mass values was set at $50 \mathrm{ppm}$ and $0.3 \mathrm{Da}$, respectively. Trypsin digestion and two possible missed cleavages were used. Only the 2 top-ranked peptide matches were taken into consideration for protein identification. Proteins with total ion score CI \%> 97 (this parameter combines p-value for MSMS identification with MASCOT score) were accepted.

\section{Quantitative response and performance of MALDI-TOF/ TOF analysis}

Quantitative accuracy and reproducibility of MALDITOF/TOF were evaluated using an internal standard (ACTH 18-39 fragment, $\mathrm{m} / \mathrm{z}$ 2465.16) added to the MALDI matrix and spotted along all the LC profile in known amount and in the same concentration in every spot. Three different concentrations (5-20 fmol/ $\mu \mathrm{l})$ were used to evaluate the linear increase of intensity with peptide concentration increase. Four replicates of each concentration were used to evaluate reproducibility.

Additional file 1: Table-TotalUniqueProteins. In the table total unique proteins are reported. The samples $\left(\mathrm{ON}, \mathrm{OFF}, 10^{\prime}\right)$ in which each protein has been identified are specified, together with the chromatographic method (anion-, cation-exchange).

\section{Acknowledgements}

This work was supported by a Research Grant of the Faculty of Medicine of the University of Pisa. We thank Laura Cignoni for her professional revision of manuscript's English.

\section{Author details}

${ }^{1}$ Institute of Clinical Physiology, CNR, Via Moruzzi 1, 56124 Pisa, Italy. ${ }^{2}$ Department of Human Morphology and Applied Biology, University of Pisa, Via Roma 55, 56126 Pisa, Italy.

\section{Authors' contributions}

SR carried out HPLC separation, mass spectrometry analysis, data interpretation, data-base interrogation and manuscript drafting and revising. LC was involved in the interpretation of analytical data and protein function assignment. CB standardized ion-exchange chromatographic technique and HPLC-MALDI conditions. NU performed sample processing in proteomic fractionation and participated in VSMC culturing. LT was involved in sample processing and protein fractionation. $\mathrm{CL}$ performed protein extract preparations. MGT performed animal surgical interventions and coronary explanting according to bioethical guidelines. AC conceived the study, optimized cell culturing and cell activation conditions, coordinated cell explanting treatments and collaborated in all the biological aspects 
concerning compilation of the manuscript. All authors read and approved the final manuscript

\section{Competing interests}

The authors declare that they have no competing interests.

Received: 30 November 2009 Accepted: 24 March 2010

Published: 24 March 2010

\section{References}

1. Wolters DA, Washburn MP, Yates JR: An Automated Multidimensional Protein Identification Technology for Shotgun Proteomics. Anal Chem 2001, 73:5683-5690.

2. Wang H, Qian WJ, Chin MH, Petyuk VA, Barry RC, Liu T, Gritsenko MA, Mottaz HM, Moore RJ, Camp li DG, Khan AH, Smith DJ, Smith RD: Characterization of the mouse brain proteome using global proteomic analysis complemented with cysteinyl-peptide enrichment. J Proteome Res 2006, 5:361-369.

3. Yang ZP, Hancock WS, Chew TR, Bonilla L: A study of glycoproteins in human serum and plasma reference standards (HUPO) using multilectin affinity chromatography coupled with RPLC-MS/MS. Proteomics 2005, 5:3353-3366.

4. Hoffman SA, Joo WA, Echan LA, Speicher DW: Higher dimensional (Hi-D) separation strategies dramatically improve the potential for cancer biomarker detection in serum and plasma. J Chromatogr B: Anal Technol Biomed Life Sci 2007, 849:43-52.

5. Hortin GL: The MALDI-TOF mass spectrometric view of the plasma proteome and peptidome. Clin Chem (Washington, DC, U. S.) 2006, 52:1223-1237.

6. Hortin GL: Can mass spectrometric protein profiling meet desired standards of clinical laboratory practice? Clin Chem (Washington, DC, U. S.) 2005, 51:3-5.

7. Bell AW, Deutsch EW, Au CE, Kearney RE, Beavis R, Sechi S, Nilsson T, Bergeron JJM, Beardslee TA, Chappell T, Meredith G, Sheffield P, Gray P, Hajivandi M, Pope M, Predki P, Kullolli M, Hincapie M, Hancock WS, Jia W, Song L, Li L, Wei J, Yang B, Wang J, Ying W, Zhang Y, Cai Y, Qian X, He F, Meyer HE, Stephan C, Eisenacher M, Marcus K, Langenfeld E, May C, Carr SA, Ahmad R, Zhu W, Smith JW, Hanash SM, Struthers JJ, Wang H, Zhang Q, An Y, Goldman R, Carlsohn E, Post van der S, Hung KE, Sarracino DA, Parker K, Krastins B, Kucherlapati R, Bourassa S, Poirier GG, Kapp E, Patsiouras H, Moritz R, Simpson R, Houle B, LaBoissiere S, Metalnikov P, Nguyen V, Pawson T, Wong CC, Cociorva D, Yates JR, Ellison MJ, Lopez-Campistrous A, Semchuk P, Wang Y, Ping P, Elia G, Dunn MJ, Wynne K, Walker AK, Strahler JR, Andrews PC, Hood BL, Bigbee WL, Conrads TP, Smith D, Borchers CH, Lajoie GA, Bendall SC, Speicher KD, Speicher DW, Fujimoto M, Nakamura K, Paik YK, Cho SY, Kwon MS, Lee HJ, Jeong SK, Chung AS, Miller CA, Grimm R, Williams K, Dorschel C, Falkner JA, Martens L, Vizcaíno JA: A HUPO test sample study reveals common problems in mass spectrometry-based proteomics. Nat Methods 2009, 6:423-430

8. Amado F, Santana-Marques MG, Ferrer-Correia ATK: Discrimination effects and sensitivity variations in matrix-assisted laser desorption/ionization. Rapid Commun Mass Spectrom 1997, 11:1347-1352.

9. Hattan SJ, Parker KC: Methodology utilizing MS signal intensity and LC retention time for quantitative analysis and precursor ion selection in proteomic LC-MALDI analyses. Anal Chem 2006, 78:7986-7996.

10. Neubert H, Bonnert TP, Rumpel K, Hunt BT, Henle ES, James IT: Label-free detection of differential protein expression by LC/MALDI mass spectrometry. J Proteome Res 2008, 7:2270-2279.

11. Owens GK, Meena SK, Wamhoff BR: Molecular regulation of vascular smooth muscle cell differentiation in development and disease. Physiol Rev 2004, 84:767-801.

12. McGregor E, Kempster L, Wait R, Welson SY, Gosling M, Dunn MJ, Powel JT: Identification and mapping of human saphenous vein medial smooth muscle proteins by two-dimensional polyacrylamide gel electrophoresis. Proteomics 2001, 11:1405-1414.

13. Taurin S, Seyrantepe V, Orlov SN, Tremblay TL, Thibault P, Bennett MR, Hamet P, Pshezhetsky AV: Proteome analysis and functional expression identify mortalin as an antiapoptotic gene induced by elevation of $\left[\mathrm{Na}^{+}\right]$ ${ }_{\mathrm{i}} /\left[\mathrm{K}^{+}\right]_{\mathrm{i}}$ ratio in cultured vascular smooth muscle cells. Circ Res 2002, 91:915-922.
14. Dupont A, Corseaux D, Dekeyzer O, Drobeca H, Guihot AL, Susen S, Vincentelli A, Amouyel P, Jude B, Pinet F: The proteome and secretome of human arterial smooth muscle cells. Proteomics 2005, 5:585-596.

15. Brisset AC, Hao H, Camenzind E, Bacchetta M, Geinoz A, Sanchez JC, Chaponnier C, Gabbiani G, Bochaton-Piallat ML: Intimal smooth muscle cells of porcine and human coronary artery express S100A4, a marker of the rhomboid phenotype in vitro. Circ Res 2007, 100:1055-1062.

16. Padrò $T$, Peña E, Garcia-Arguinzonis M, Llorente-Cortes V, Badimon L: Lowdensity lipoproteins impair migration of human coronary vascular smooth muscle cells and induce changes in the proteomic profile of myosin light chain. Card Res 2007, 77:211-220.

17. Bian $Y L, Q i Y X$, Yan ZQ, Long DK, Shen BR, Jiang ZL: A proteomic analysis of aorta from spontaneously hypertensive rat: RhoGDI alpha upregulation by angiotensin II via AT1 receptor. Eur J Cell Biol 2008, 87:101-110.

18. Mayr U, Mayr M, Yin X, Begum S, Tarelli E, Wait R, Qingbo Xu Q: Proteomic dataset of mouse aortic smooth muscle cells. Proteomics 2005, 5:4546-4557.

19. Poliseno L, Cecchettini A, Evangelista M, Ricci F, Giorgi F, Citti L, Rainaldi G: Resting smooth muscle cells as a model for studying vascular cell activation. Tissue \& Cell 2004, 38:111-120.

20. Christen T, Bochaton-Piallat ML, Neuville P, Renzen S: Cultured porcine coronary artery smooth muscle cells: a new model with advanced differentiation. Circ Res 1999, 85:99-107.

21. Qian WJ, Jacobs JM, Liu T, Camp DG II, Smith RD: Advances and challenges in liquid chromatography-mass spectrometry based proteomic profiling for clinical application. Mol Cell Proteomics 2006, 5:1727-1744

22. Manadas B, English JA, Wynne KJ, Cotter DR, Dunn MJ: Comparative analysis of OFFGel, SCX with $\mathrm{pH}$ gradient, and reverse phase at high $\mathrm{pH}$ for first dimensional separation of peptides from a membrane enriched protein fraction. Proteomics 2009, 9:5194-5198.

23. Martin-Ventura JL, Nicolas V, Houard X, Blanco-Colio LM, Leclercq A, Egido J, Vranckx R, Michel JB, Meilhac O: Biological Significance of Decreased HSP27 in Human Atherosclerosis. Arterioscler Thromb Vasc Biol 2006, 26:1337-1343.

24. Hattan SJ, Marchese J, Khainovski N, Martin S, Juhasz P: Comparative study of [three] LC-MALDI workflows for the analysis of complex proteomic samples. J Proteome Res 2005, 4:1931-1941.

25. Boccardi C, Cecchettini A, Caselli A, Camici G, Evangelista M, Mercatanti A, Rainaldi G, Citti L: A proteomic approach to the investigation of early events involved in vascular smooth muscle cell activation. Cell Tissue Res 2007, 328:185-195.

26. Gerthoffer WT: Mechanisms of vascular smooth muscle cell migration Circ Res 2007, 100:607-621.

27. Benkali $K$, Marquet $P$, Rerolle JP, Le Meur $Y$, Gastinel LN: A new strategy for faster urinary biomarkers identification by Nano-LC-MALDI-TOF/TOF mass spectrometry. BMC Genomics 2008, 9:541.

\section{doi:10.1186/1477-5956-8-15}

Cite this article as: Rocchiccioli et al:: A gel-free approach in vascular smooth muscle cell proteome: perspectives for a better insight into activation. Proteome Science 2010 8:15.

\section{Submit your next manuscript to BioMed Central and take full advantage of:}

- Convenient online submission

- Thorough peer review

- No space constraints or color figure charges

- Immediate publication on acceptance

- Inclusion in PubMed, CAS, Scopus and Google Scholar

- Research which is freely available for redistribution 